\title{
PORTAL OF CLUSTERS AND COMPETITIVENESS POLES IN THE
} TEXTILE-CLOTHING SECTOR

\author{
SABINA OLARU, CĂTĂLIN GROSU, EFTALEA CĂRPUŞ, CARMEN GHIȚULEASA \\ The National Research Development Institute for Textiles and Leather, 16 Lucretiu Patrascanu, \\ 030508,Bucharest, Romania, sabina.olaru@certex.ro
}

\begin{abstract}
The remarkable advances in technological development and innovation, which have taken place in the last few years, have influenced the organization and business strategies. The knowledge revolution was identified, a complex process of transition from the physical to knowledge-based economy, in which intangible intellectual resources, knowledge packages and informational capital play an essential strategic role, being the engine of competitiveness. In order to support the members of the national textile-clothing clusters, the members of the competitiveness pole in the related fields, the stakeholders, a portal of competitiveness clusters and poles in the textile clothing industry was created and developed. The portal functions as a common platform that concentrates information on the activity of clusters and competitiveness poles in the T\&C sector, in order to facilitate the effective interaction and collaboration of actors in the sector. The main goal of this portal is to support the competitiveness of the Romanian clusters in the T\&C industry, by increasing their visibility on the national market. Through this approach, it is intended to promote a development based on cooperation among cluster members and a relational system between both cluster members and stakeholders.
\end{abstract}

Keywords: cluster, textile-clothing, portal, competitiveness

\section{INTRODUCTION}

The remarkable advances in technological development and innovation, which have taken place in the last few years, have influenced the organization and business strategies. The knowledge revolution was identified, a complex process of transition from the physical to knowledge-based economy, in which intangible intellectual resources, knowledge packages and informational capital play an essential strategic role, being the engine of competitiveness (Lut, 2012).

Ensuring social well-being and added value is possible through a systematic generation and efficient use of knowledge. Thus, among developed countries, the trend is the development of national systems with complex international interactions, called by specialists: "triangles of knowledge". "The triangle of knowledge" consists of education, research and innovation and is realized through cooperation between education institutions, research organizations and the business environment (Dan, 2012; Irecson, 2009). Among these, the greatest degree of complexity that raises the most problems (specific policies, well-prepared human resources, financial resources to be allocated) is innovation. Innovation is a function of many variables due to the role it plays as a link element (bridge between research and industry). The innovative process does not end with the implementation of new products and services in the industry, but it is continuously developing in order to improve these products and services to be competitive.

The ultimate consumer, through his needs, changing with astonishing dynamics, demands the acceleration of the innovative process. Reducing development time in innovative products and services, implemented in industry, leads to the acceleration of the economic circuit and thus to the increase of final consumer satisfaction (European Commission, 2010). 


\section{THE PORTAL ARCHITECTURE OF CLUSTERS AND POLES OF COMPETITIVENESS FROM TEXTILE \& CLOTHING FIELD}

In order to support the final users: members of the national textile-clothing clusters, members of the competitiveness poles in the related fields, stakeholders, a portal of competitiveness clusters and poles in the textile - clothing industry was created and developed. The portal functions as a common platform that concentrates information on the activity of clusters and competitiveness poles in the $\mathrm{T} \& \mathrm{C}$ sector, in order to facilitate the effective interaction and collaboration of actors in the sector.

The main goal of this portal is to support the competitiveness of the Romanian clusters in the T\&C industry, by increasing their visibility on the national market.

The portal is a vector for the development of the Romanian clusters and competitiveness poles.

Through this approach, it is intended to promote a development based on cooperation among cluster members and a relational system between both cluster members and stakeholders by promoting the textile industry and increasing the visibility of Romanian textiles on the national and European market.

The portal functions as a platform that can be upgraded and expanded with up-todate information. The user of the portal must find the right information in a minimum search time. Thus, designing a user-friendly platform has been a very important goal of this phase. The portal was designed and built in Romanian. To achieve the site a WYSIWYG program (What You See Is What You Get), Joomla! 3.8.0 - toolkit for building a professional site has been used. Joomla is a PHP Content Management System (CMS) designed to publish content locally or online through SQL databases. Joomla offers the ability to build complex web sites and applications (Figure 1).

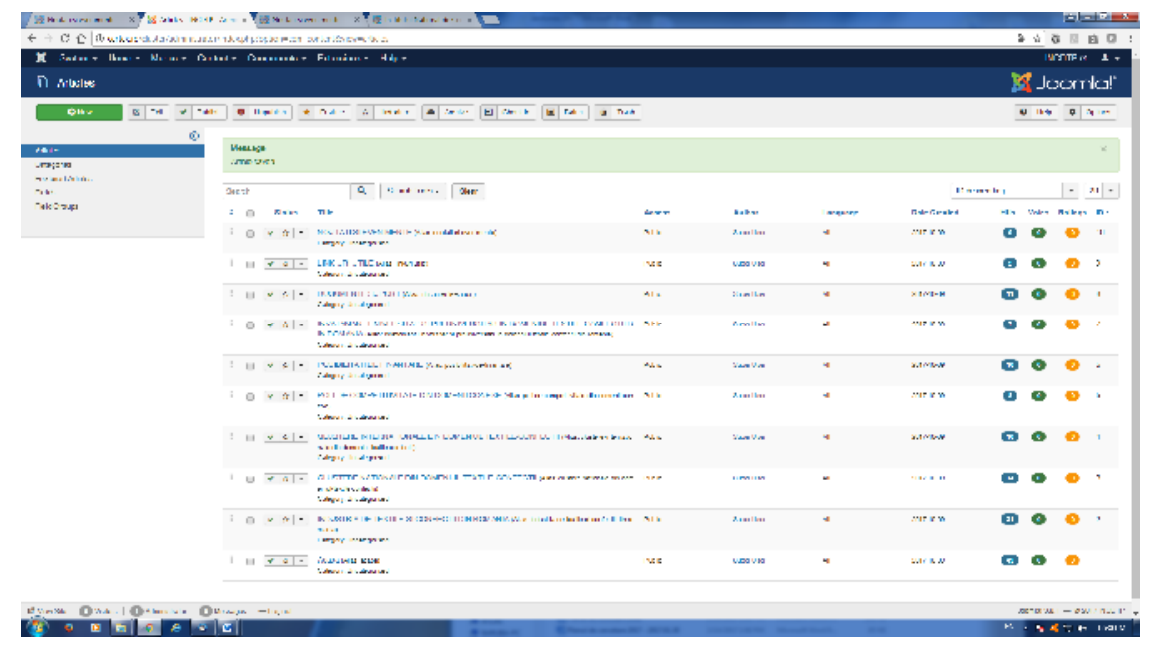

Figure 1. Joomla articles manager

The portal, accessible on the website of the National Research \& Development Institute for Textiles and Leather, from Bucharest, at http://www.certex.ro/cluster/, comprises 11 sections, which focus on:

- Definition of the cluster, the innovation cluster and the competitiveness pole; 
information on the role and effects of each actor in a cluster / competitiveness pole, namely the policy and strategy of clusters / competitiveness poles (section - Home) (Figure 2) (Coşniţă and Bucur, 2013);

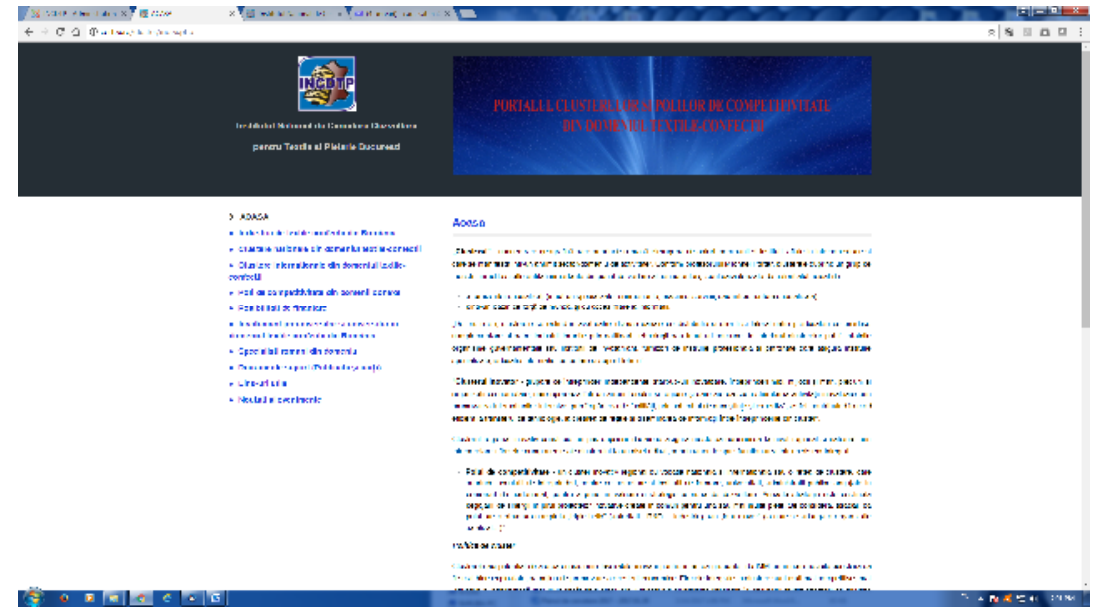

Figure 2. "Home" section

- The short history, in which are presented: the main events that marked the textile industry in Romania; data on the economic situation of textile \& clothing field in 2015 (section - Textile \& Clothing Industry in Romania);

- The charts with updated information on cluster activity: general information (logo; name; year of establishment; contact person; telephone / fax; headquarters address; email; website; management team; excellence label; participation in other networks / partnerships); field of activity (areas of specialization, domains targeted for intersectoral collaborations); members (total number, total number of SMEs, SME identification data, universities, research institutes, public authorities, catalysts, others); cluster / pole strategy (missions, general objectives, specific objectives); the main products / services / projects offered (products, services, projects, main markets, international collaborations, industry turnover - 2015, industry turnover - 2016, 2015, number of employees in 2016). All this information was centralized for the 4 national clusters of the textile \& clothing: Romanian Textile Concept, Bucharest; Traditions Manufacture Future, Focsani, Vrancea; Transylvania Textile \& Fashion Sfântu Gheorghe Covasna; ASTRICO N-E, Săvineşti, Neamţ and Noatex - meta cluster that reunites the four clusters mentioned above. (Section - National Clusters of the Textile \& Clothing) (Figure 3);

- The general information on mission of the main Textile \& Clothing European and international clusters and contact data of these clusters (Section - International Clusters of Clusters of the Textile \& Clothing);

- Up-to-date information on the activity of the Romanian Poles of Competitiveness: Southwest Automotive Oltenia, Ind-Agro-Pol and Ro-Health, where INCDTP has membership (general information; mission; field of activity; members; contact data;) (Section - Poles of Competitiveness in related fields);

- The information on funding opportunities for clusters under specific programs such 
as: Eureka Cluster - PNIII program, P3: European and International Cooperation: Subprogram 3.5: Other European and International Initiatives and Programs: EUREKA Traditional (Network), EUREKA Cluster, EUROSTARS; "Cluster Organization and Development - Innovative Cluster" (Section - Financing possibilities);

- The brief information on Romanian university level education (Section - Preuniversity and university education in the field of textile \& clothing, in Romania);

- Section designed for the experts (specialists) in the field of textiles \& clothing, at national level (Section - Romanian specialists in the field);

- Presentation of Romanian and international publications that define clusters and poles of competitiveness, strategies, economic measures on increasing internationalization process, intelligent recommendations on clusters, etc. (Section Supporting Documents) (Pavelkova et al., 2016);

- The main institutions, organizations and platforms that provide a mapping of European clusters, statistical data, analysis, favoring the implementation of EU policies at regional level; a short description of the two textile and clothing journals in Romania: "Industria Textilă" and "Dialog Textil" (section - Useful Links).

- Up-to-date information that helps better dissemination amongst the clusters and poles of the competitiveness of the events and news in the sector (section - News and Events).

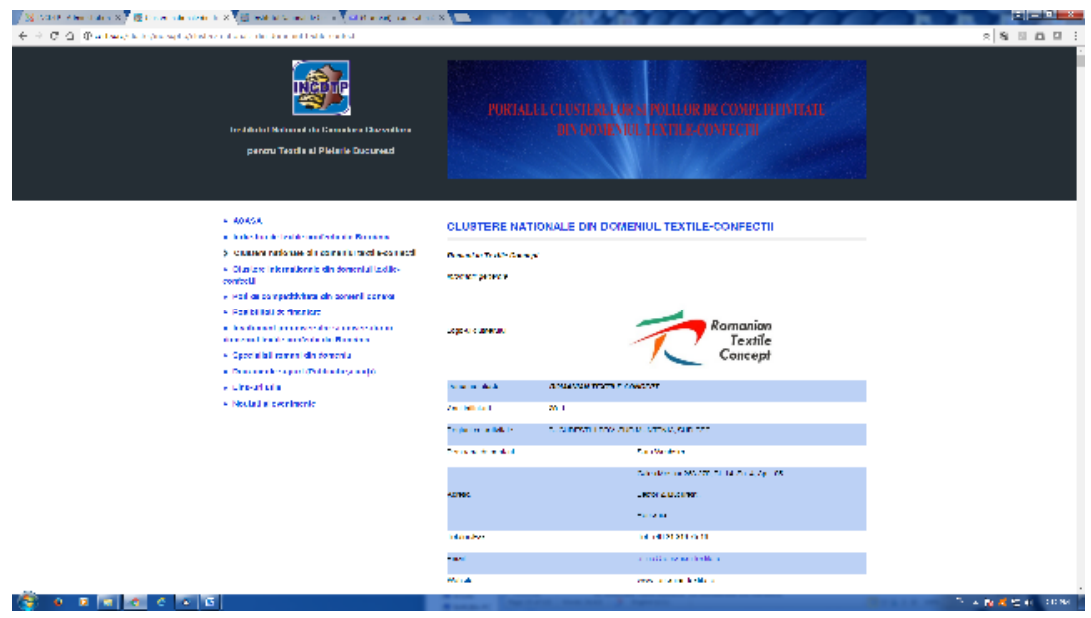

Figure 3. Section - "National Clusters in the field of Textiles \& Clothing"

\section{CONCLUSIONS}

The paper presents the portal architecture of the clusters and poles of competitiveness in the textile \& clothing industry. The content of the portal is structured into 11 sections, whose information is addressed to industry actors, universities, research institutes, local and regional public authorities, catalysts and other stakeholders.

According to the strategic objectives and the Romanian and European action directions in the field of clusters, the portal leads to the increase of the competitiveness of clusters in the textile \& clothing industry. 
The Romanian cluster structure, "Four clover" type, is fully found in the four Romanian textile clusters: Romanian Textile Concept, Bucharest; Traditions Manufacture Future, Focsani, Vrancea; Transylvania Textile \& Fashion Sfântu Gheorghe Covasna; ASTRICO N-E, Săvineşti, Neamţ, so that the synergy between the constituent actors will lead to positive results.

\section{REFERENCES}

Coşniţă, D. and Bucur, D. (2013), "Clusterization in textile and clothing industry", Proceedings of $6^{\text {th }}$ TEXTEH International Conference, Bucharest, Romania, 274-288.

Dan, M.C. (2012), "Clusterele inovative: o solutie pentru dezvoltarea economica a Romaniei”, Economie teoretica si aplicata, vol. XIX, no. 9(574), 3-14.

European Commission (2010), "EUROPE 2020: A strategy for smart, sustainable and inclusive growth", Brussels.

Irecson (2009), "Ghid pentru implementarea in Romania a conceptului de cluster inovativ", Bucharest, http://www.inma-ita.ro/clustere/Ghid.pdfhttp://www.nwtexnet.co.uk/

Lut, D. (2012), "The role and importance of clusters in the context of the knowledge economy", Timisoara, "Dimitrie Cantemir" Christian University, available at: http://www.quaestus.ro/wpcontent/uploads/2012/03/D.-Lut.pdf.

Pavelkova, D. et al. (2016), Internationalization of Cluster Organizations: Strategy, Policy and Competitiveness, Cambridge Scholar Publishing.

Porter, M.E. (1985), The Competitive Advantage: Creating and Sustaining Superior Performance, Free Press, New York. 